\section{Crop Rotation Minimizes Losses from Corky Root in Florida Lettuce}

\author{
J. Alvarez, L.E. Datnoff, and R.T. Nagata \\ Everglades Research and Education Center, University of Florida, Belle \\ Glade, FL 33430
}

Additional index words. Lactuca sativa, Histosols, Rhizomonas suberifaciens, profitability, yield losses

\begin{abstract}
The severity of corky root disease (Rhizomonas suberifaciens Van Bruggen et al.) increases with continuous lettuce (Lactuca sativa $L$.) cropping and exerts a negative impact on the quantity and quality of the lettuce produced. Experimental data from commercial fields were used to analyze profitability outcomes resulting from various management strategies, including cultivars, locations, and field cropping history, to control corky root. Regardless of the field cropping history, net returns were not negatively affected when resistant cultivars were planted. For susceptible cultivars, even when considering land development costs, producers maximize net returns by planting lettuce following sugarcane in land not previously cropped to lettuce. After the first crop of lettuce following sugarcane, yields slowly decreased but remained profitable for three to four crop cycles.
\end{abstract}

Corky root (CR) of lettuce is a disease caused by Rhizomonas suberifaciens (van Bruggen et al., 1990) that has been reported in several production areas of the United States and other countries (Busch and Baron, 1963; Datnoff and Nagata, 1990; D'Ercole, 1981; van Bruggen et al., 1989). This disease has been observed in Florida since the 1970s and CR-resistant crisphead lettuce cultivars have been developed to replace some of those susceptible (Datnoff and Nagata, 1992, Guzman, 1984).

Other than the use of resistant cultivars, crop rotation is the only viable means of controlling losses due to CR. Although soil fumigation is effective in controlling $\mathrm{CR}$, it is prohibitively expensive under field condigeneral practice in Florida is to rotate vegetable production with sugarcane. In the majority of cases, and because lettuce is cropped more intensively than other crops, when land is prepared for lettuce production it is farmed as long as possible to spread land development costs (roads, ditches, culverts and pumps, fertilization, laser leveling, and weed control) over as many crops as possible.

In normal market conditions, and in times of excess supplies, lettuce is marketed in 1.6$\mathrm{kg}$ cartons that contain 24 heads averaging at least $785 \mathrm{~g}$ each, for a total weight of at least $20 \mathrm{~kg}$. When supplies are short, the market will take cartons weighing as little as $16 \mathrm{~kg}$. Although CR exerts a negative impact on yield and quality, the impact of $\mathrm{CR}$ on lettuce profitability depends on market conditions at the time of selling.

Research in Florida has provided estimates of losses in weight and the number of

Received for publication 22 Apr. 1991. Accepted for publication 15 Aug. 1991. Florida Agricultural Experiment Stations Journal Series no. R-01724. The cost of publishing this paper was defrayed in part by the payment of page charges. Under postal regulations, this paper therefore must be hereby marked advertisement solely to indicate this fact. tions (O'Brien and van Bruggen, 1990). The marketable heads for resistant and susceptible cultivars at various levels of disease severity (Datnoff and Nagata, 1992). There were wide variations in yield losses due to field history and cultivars. We undertook this economic analysis to compare the profitability outcomes resulting from several CR management strategies that included cultivars, locations, and cropping history.

Field studies. We used data from experiments conducted on commercial fields during Fall 1988 and Spring-Fall 1989 to perform the economic analysis. The production practices used have been described in detail (Dat- noff and Nagata, 1992). Briefly, the CRresistant crisphead cultivars Raleigh and South Bay and the CR-susceptible 'Ithaca' and 'Shawnee' were planted in a randomized complete block design with eight replications in locations $\mathrm{A}, \mathrm{B}, \mathrm{C}, \mathrm{D}$, and $\mathrm{E}$ on the same date. Locations A and B had been cropped continuously to lettuce for the past 6 years; Location $\mathrm{C}$ was in lettuce production for 3 years. Locations $\mathrm{D}$ and $\mathrm{E}$ had been in sugarcane production for the past 20 years and never cropped to lettuce. Total aboveground fresh and marketable trim weights were recorded at harvest maturity using standard grading procedures (U.S. Dept. of $\mathrm{Ag}$ riculture, 1973).

We randomly harvested 10 heads of each cultivar in each of the eight replications, for a total of 160 observations/cultivar in each location.

Data handling. For each location, we counted the number of heads with a weight of at least 785,690 , and $596 \mathrm{~g}$ that would correspond to carton weights of 20.4, 18.1, and $15.9 \mathrm{~kg}$, respectively, for both the resistant and susceptible cultivars. We then divided that number by 160 to obtain the percentage of the crop falling into each of the three marketing categories in each location (Table 1). The percentage figures were then multiplied times the 60,000 plants/ha and divided by the 24 heads contained in each carton (Table 2).

Economic analysis. We derived profitability outcomes for the management strategies from the following profit equation: $\mathrm{E}(\pi)$ $=\left[\mathrm{P}_{\mathrm{L}}, \times \mathrm{Y}_{\mathrm{i}},(\mathrm{X})\right]-\left[\mathrm{H} \times \mathrm{Y}_{\mathrm{i}}(\mathrm{X})\right]-\mathrm{PHC}$; where $E(\pi)=$ expected value of profits (dollars/ha); $\mathrm{P}_{\mathrm{L}}=$ price of lettuce (dollars
Table 1. Percentage of lettuce cultivars resistant and susceptible to corky root falling into each of the three marketing categories by location.

\begin{tabular}{|c|c|c|c|c|c|c|c|c|}
\hline \multirow[b]{2}{*}{ Location $^{2}$} & \multicolumn{4}{|c|}{ Resistant cultivars ( $\geq \mathrm{g} /$ head) ${ }^{y}$} & \multicolumn{4}{|c|}{ Susceptible cultivars $\left(\geq \mathrm{g} /\right.$ head $^{\mathrm{y}}$} \\
\hline & 785 & 690 & 596 & Total & 785 & 690 & 596 & Total \\
\hline & \multicolumn{8}{|c|}{ Percent } \\
\hline $\begin{array}{l}\text { A } \\
\text { B } \\
\text { C } \\
\text { D } \\
\text { E }\end{array}$ & $\begin{array}{l}21.9 \\
76.9 \\
41.9 \\
50.0 \\
77.5\end{array}$ & $\begin{array}{l}46.9 \\
87.5 \\
68.8 \\
71.9 \\
96.2\end{array}$ & $\begin{array}{l}70.6 \\
95.0 \\
84.4 \\
86.9 \\
99.4\end{array}$ & $\begin{array}{l}70.6 \\
95.0 \\
84.4 \\
86.9 \\
99.4\end{array}$ & $\begin{array}{c}0 \\
1.2 \\
48.1 \\
58.7 \\
70.6\end{array}$ & $\begin{array}{c}0 \\
8.7 \\
71.9 \\
81.9 \\
92.5\end{array}$ & $\begin{array}{c}0 \\
20.6 \\
86.9 \\
91.2 \\
97.4\end{array}$ & $\begin{array}{c}0 \\
20.6 \\
86.9 \\
91.3 \\
97.5\end{array}$ \\
\hline
\end{tabular}

${ }^{\mathrm{z}} \mathrm{A}$ and $\mathrm{B}-$ cropped continuously to lettuce for the past 6 years; $\mathrm{C}-$ for 3 years; $\mathrm{D}$ and $\mathrm{E}-$ sugarcane continuously for 20 years before lettuce.

${ }^{y}$ Missing percentages were classified as culls (unmarketable under any circumstance). Yield differences, especially for resistant cultivars, are partly due to environmental and/or cultural factors other than corky root.

Table 2. Calculated yields per hectare in the three marketing categories for lettuce cultivars resistant and susceptible to corky root by location.

\begin{tabular}{lrllrrr}
\hline \hline & \multicolumn{5}{c}{ Total yield (cartons/ha) } \\
\cline { 2 - 7 } & \multicolumn{5}{c}{ Resistant cultivars } & \multicolumn{3}{c}{ Susceptible cultivars } \\
\cline { 2 - 7 } & \multicolumn{7}{c}{ Minimum carton wt } \\
\cline { 2 - 7 } Location $^{2}$ & $\mathbf{2 0 . 4}$ & 18.1 & 15.9 & 20.4 & $\mathbf{1 8 . 1}$ & $\mathbf{1 5 . 9}$ \\
\hline $\mathrm{A}$ & 547 & 1172 & 1765 & 0 & 0 & 0 \\
B & 1922 & 2187 & 2374 & 31 & 218 & 515 \\
C & 1047 & 1719 & 2109 & 1203 & 1796 & 2171 \\
D & 1250 & 1796 & 2171 & 1468 & 2046 & 2281 \\
E & 1937 & 2405 & 2483 & 1765 & 2311 & 2436 \\
\hline
\end{tabular}

${ }^{2} \mathrm{~A}$ and $\mathrm{B}-$ cropped continuously to lettuce for the past 6 years; $\mathrm{C}-$ for 3 years; $\mathrm{D}$ and $\mathrm{E}$-sugarcane continuously for 20 years before lettuce. 
Table 3. Calculated net returns from lettuce cultivars resistant (RES) and susceptible (SUS) to corky root in times of normal and short supplies by location.

\begin{tabular}{|c|c|c|c|c|c|c|}
\hline \multirow{3}{*}{$\begin{array}{l}\text { Location- } \\
\text { cultivar- } \\
\text { carton type }\end{array}$} & \multicolumn{3}{|c|}{ Normal supplies ${ }^{2}$} & \multicolumn{3}{|c|}{ Short supplies ${ }^{y}$} \\
\hline & \multicolumn{3}{|c|}{ Lettuce price (\$/carton) } & \multicolumn{3}{|c|}{ Lettuce price (\$/carton) } \\
\hline & 6 & 7 & 8 & 10 & 11 & 12 \\
\hline $\begin{array}{c}\text { A, RES } \\
20.4 \\
18.1 \\
15.9\end{array}$ & $\begin{array}{l}-1,400 \\
-3,045^{w} \\
-3,045\end{array}$ & $\begin{array}{l}-860 \\
-3,045 \\
-3,045\end{array}$ & $\begin{array}{l}-310 \\
-3,045 \\
-3,045\end{array}$ & $\begin{array}{c}780 \\
5,160 \\
9,310\end{array}$ & $\begin{array}{r}1,330 \\
6,330 \\
11,070\end{array}$ & $\begin{array}{r}1,880 \\
7,500 \\
12,840\end{array}$ \\
\hline $\begin{array}{c}\text { A, SUS } \\
20.4 \\
18.1 \\
15.9\end{array}$ & $\begin{array}{l}-3,045 \\
-3,045 \\
-3,045\end{array}$ & $\begin{array}{l}-3,045 \\
-3,045 \\
-3,045\end{array}$ & $\begin{array}{l}-3,045 \\
-3,045 \\
-3,045\end{array}$ & $\begin{array}{l}-3,045 \\
-3,045 \\
-3,045\end{array}$ & $\begin{array}{l}-3,045 \\
-3,045 \\
-3,045\end{array}$ & $\begin{array}{l}-3,045 \\
-3,045 \\
-3,045\end{array}$ \\
\hline $\begin{array}{c}\text { B, RES } \\
20.4 \\
18.1 \\
15.9\end{array}$ & $\begin{array}{r}2,720 \\
-3,045 \\
-3,045\end{array}$ & $\begin{array}{r}4,640 \\
-3,045 \\
-3,045\end{array}$ & $\begin{array}{r}6,560 \\
-3,045 \\
-3,045\end{array}$ & $\begin{array}{l}10,410 \\
12,260 \\
13,570\end{array}$ & $\begin{array}{l}12,330 \\
14,450 \\
15,950\end{array}$ & $\begin{array}{l}14,250 \\
16,640 \\
18,321\end{array}$ \\
\hline $\begin{array}{c}\text { B, SUS } \\
20.4 \\
18.1 \\
15.9\end{array}$ & $\begin{array}{l}-2,950 \\
-3,045 \\
-3,045\end{array}$ & $\begin{array}{l}-2,920 \\
-3,045 \\
-3,045\end{array}$ & $\begin{array}{l}-2,890 \\
-3,045 \\
-3,045\end{array}$ & $\begin{array}{c}-2,830 \\
-1,520 \\
560\end{array}$ & $\begin{array}{r}-2,800 \\
-1,300 \\
1,070\end{array}$ & $\begin{array}{r}-2,770 \\
-1,080 \\
1,590\end{array}$ \\
\hline $\begin{array}{c}\text { C, RES } \\
20.4 \\
18.1 \\
15.9\end{array}$ & $\begin{array}{r}96 \\
-3,045 \\
-3,045\end{array}$ & $\begin{array}{r}1,140 \\
-3,045 \\
-3,045\end{array}$ & $\begin{array}{r}2,190 \\
-3,045 \\
-3,045\end{array}$ & $\begin{array}{r}4,280 \\
8,990 \\
11,720\end{array}$ & $\begin{array}{r}5,330 \\
10,710 \\
13,830\end{array}$ & $\begin{array}{r}6,380 \\
12,430 \\
15,940\end{array}$ \\
\hline $\begin{array}{c}\text { C, SUS } \\
20.4 \\
18.1 \\
15.9\end{array}$ & $\begin{array}{c}560 \\
-3,045 \\
-3,045\end{array}$ & $\begin{array}{r}1,770 \\
-3,045 \\
-3,045\end{array}$ & $\begin{array}{r}2,970 \\
-3,045 \\
-3,045\end{array}$ & $\begin{array}{r}5,380 \\
9,530 \\
12,150\end{array}$ & $\begin{array}{r}6,580 \\
11,320 \\
14,320\end{array}$ & $\begin{array}{r}7,780 \\
13,120 \\
16,490\end{array}$ \\
\hline $\begin{array}{c}\text { D, RES } \\
20.4 \\
18.1 \\
15.9\end{array}$ & $\begin{array}{r}700 \\
-3,045 \\
-3,045\end{array}$ & $\begin{array}{r}1,950 \\
-3,045 \\
-3,045\end{array}$ & $\begin{array}{r}3,200 \\
-3,045 \\
-3,045\end{array}$ & $\begin{array}{r}5,700 \\
9,530 \\
12,150\end{array}$ & $\begin{array}{r}6,950 \\
11,320 \\
14,320\end{array}$ & $\begin{array}{r}8,200 \\
13,120 \\
16,490\end{array}$ \\
\hline $\begin{array}{c}\mathrm{D}, \text { SUS } \\
20.4 \\
18.1 \\
15.9\end{array}$ & $\begin{array}{r}1,360 \\
-3,045 \\
-3,045\end{array}$ & $\begin{array}{r}2,830 \\
-3,045 \\
-3,045\end{array}$ & $\begin{array}{r}4,290 \\
-3,045 \\
-3,045\end{array}$ & $\begin{array}{r}7,230 \\
11,280 \\
12,920\end{array}$ & $\begin{array}{r}8,700 \\
13,320 \\
15,200\end{array}$ & $\begin{array}{l}10,170 \\
15,370 \\
17,480\end{array}$ \\
\hline $\begin{array}{c}\text { E, RES } \\
20.4 \\
18.1 \\
15.9\end{array}$ & $\begin{array}{r}2,770 \\
-3,045 \\
-3,045\end{array}$ & $\begin{array}{r}4,700 \\
-3,045 \\
-3,045\end{array}$ & $\begin{array}{r}6,640 \\
-3,045 \\
-3,045\end{array}$ & $\begin{array}{l}10,510 \\
13,790 \\
14,340\end{array}$ & $\begin{array}{l}12,450 \\
16,190 \\
16,820\end{array}$ & $\begin{array}{l}14,390 \\
18,600 \\
19,300\end{array}$ \\
\hline $\begin{array}{c}\text { E, SUS } \\
20.4 \\
18.1 \\
15.9\end{array}$ & $\begin{array}{r}2,250 \\
-3,045 \\
-3,045\end{array}$ & $\begin{array}{r}4,010 \\
-3,045 \\
-3,045\end{array}$ & $\begin{array}{r}5,780 \\
-3,045 \\
-3,045\end{array}$ & $\begin{array}{r}9,310 \\
13,130 \\
14,010\end{array}$ & $\begin{array}{l}11,070 \\
15,440 \\
16,440\end{array}$ & $\begin{array}{l}12,840 \\
17,750 \\
18,880\end{array}$ \\
\hline
\end{tabular}

${ }^{2}$ Market will take $20.4 \mathrm{~kg}$ cartons only.

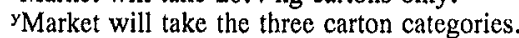

xLocation with zero marketable production.

wTotal operating preharvest costs.

per carton); $\mathrm{Y}_{i}(\mathrm{X})=$ implicit lettuce yield function (cartons/ha); $\mathrm{i}=$ the ith location (A, B, C, D, or E); $\mathrm{H}=$ harvest and marketing costs (dollars per carton); and PHC $=$ total operating preharvest costs (dollars/ ha).

We used data from various sources, Prices of $\$ 6, \$ 7$, and $\$ 8 / 20.4-\mathrm{kg}$ carton for normal market conditions (usually from February through May) and of $\$ 10, \$ 11$, and $\$ 12 /$ tarton of the three weights described above for times when supplies are short (usually from October through January) were selected as based on the historical range observed from the 1982-83 through 1988-89 season (Florida Dept. of Agriculture and Consumer Services, 1990). Lettuce yields were obtained from the experimental data shown in Table 2. Total operating preharvest costs were $\$ 3045 /$ ha, while harvest and marketing costs were \$3/carton (Taylor and Smith, 1990).

We also calculated expected net returns during the 1988-89 and 1989-90 seasons. We used the same data, except for the total operating preharvest costs of \$2912/ha for the 1988-89 season (Taylor and Smith, 1989), and the actual prices from November through May (Florida Dept. of Agriculture and Consumer Services, 1990).

Under markets with both normal and short supplies, the expected net returns reflect the yields in Tables 1 and 2 (Table 3). For resistant cultivars, a consistent relationship between $\mathrm{CR}$ and profitability is not present. Although net returns decrease from locations $\mathrm{D}$ and $\mathrm{E}$ to location $\mathrm{C}$, they increase in location $\mathrm{B}$ and decrease again in location $\mathrm{A}$. Environmental and/or cultural factors, and not CR, are probably responsible for that inconsistency. In the case of susceptible cul- tivars, there is a consistent negative relationship between the amount of CR in the field and profitability. Net returns descend from newly developed fields (locations D and E) to fields in lettuce production for 3 years (location C) and, finally, to fields that had been continuously cropped to lettuce for 6 years (locations A and B). Apparently, inoculum density of the pathogen increases over time in fields continuously cropped to lettuce.

The $\$ 3045$ negative net returns shown in Table 3 are the total operating preharvest costs incurred when unfavorable market conditions are present. Other negative expected net returns represent the potential losses when yields are not high enough to recover preharvest costs. In those cases, producers have the choice of abandoning the field or harvesting to minimize losses due to $C R$. 
Table 4. Average expected net returns per hectare with continuous harvesting, 1988-89 and $1989-90$.

\begin{tabular}{lcrr}
\hline \hline & & \multicolumn{2}{c}{ Season $^{\mathrm{x}}$} \\
\cline { 3 - 4 } Location $^{\mathrm{z}}$ & Cultivar $^{\mathrm{y}}$ & \multicolumn{1}{c}{ 1988-89 } & $1989-90$ \\
\hline & & \multicolumn{2}{c}{ Dollars/ha } \\
$\mathrm{A}$ & $\mathrm{R}$ & 4,760 & 4,640 \\
& $\mathrm{~S}$ & $-2,910$ & $-3,040$ \\
$\mathrm{~B}$ & $\mathrm{R}$ & 9,700 & 11,990 \\
& $\mathrm{~S}$ & -920 & -950 \\
$\mathrm{C}$ & $\mathrm{R}$ & 7,020 & 8,680 \\
& $\mathrm{~S}$ & 7,550 & 9,300 \\
$\mathrm{D}$ & $\mathrm{R}$ & 7,640 & 9,390 \\
& $\mathrm{~S}$ & 8,480 & 10,590 \\
$\mathrm{E}$ & $\mathrm{R}$ & 10,140 & 12,740 \\
& $\mathrm{~S}$ & 9,630 & 12,100 \\
\hline
\end{tabular}

${ }^{2} \mathrm{~A}$ and $\mathrm{B}-$ lettuce continuously for past 6 years $\mathrm{C}-$ for 3 years; $\mathrm{D}$ and $\mathrm{E}-$ sugarcane for 20 years before lettuce.

${ }^{\mathrm{y}} \mathrm{R}=$ resistant; $\mathbf{S}=$ susceptible.

xFrom November through May. Prices for the 198889 season were $\$ 13.45, \$ 11.43, \$ 10.35, \$ 7.47$, $\$ 6.88, \$ 6.03$, and $\$ 5.17$ per carton, respectively. Prices for the 1989-90 season were $\$ 17.63, \$ 11.07$, $\$ 9.36, \$ 7.20, \$ 7.20, \$ 7.92$, and $\$ 8.41$ per carton, respectively.

The previous discussion becomes more relevant when analyzing the incidence of lettuce prices. Time series data from the 198283 through 1989-90 season include 58 average monthly prices (Florida Dept. of Agriculture and Consumer Services, 1990). Average monthly prices of up to $\$ 8 /$ carton (defined as normal supplies) occurred 31 times (53\%), while those higher than $\$ 10$ (defined as short supplies) were present 13 times ( $22 \%$ ), with the remaining 14 prices falling in between $(24 \%)$. If the price incidence of the past eight seasons is a true indicator of price probabilities, producers can expect to market only $20.4-\mathrm{kg}$ cartons $\approx 53 \%$ of the time and all carton types $\approx 22 \%$ of the time. In addition, 20.4- and 18.1-kg cartons can be marketed $\approx 24 \%$ of the time. Since prices show a seasonal pattern, lettuce profitability depends on the time of year the crop is produced.

Florida producers, however, market their lettuce throughout the season, i.e., from November to early May. When the actual prices of the last two seasons are used in the calculation of expected net returns, the results show the negative impact of $\mathrm{CR}$ on lettuce profitability and indicate a potential $\mathrm{CR}$ management strategy (Table 4). Abstracting from other environmental factors, the differences in expected net returns between resistant and susceptible cultivars in locations A and $\mathrm{B}$ (in lettuce production for the previous 6 years) show the devastating impact of CR on lettuce profitability. The return figures from both seasons parallel the results obtained in Table 3: a) no consistent relationship between CR and profitability is present with resistant cultivars; b) expected net returns with susceptible cultivars decrease from locations $\mathrm{D}$ and $\mathrm{E}$ to $\mathrm{C}$ and to $\mathrm{A}$ and $\mathrm{B}$; and c) expected net returns from resistant cultivars are higher than those from susceptible cultivars in locations A and B, but both are very similar to returns in the other locations.

Land development costs were not included in the economic analysis. A land development cost of $\$ 717 /$ ha was suggested by local producers. After dividing it by 10 , to account for the 4 years in production with 2.5 crops per year, we arrived at a figure of $\$ 72 /$ crop. From an economic standpoint, it is reasonably clear that marketing implications override everything else. For example, if we were to amortize $\$ 717$ at $12 \%$ over 4 years (borrowed on annual basis and paid annually), the resulting figure would be $\$ 240$ / year or $\$ 96 /$ crop. That figure is relatively insignificant given the magnitude of the data based on the market conditions shown above.

The previous analyses indicate that no rotation is needed when resistant cultivars are planted, at least for the duration of our experiments. For susceptible cultivars, even considering land development costs and land availability, producers maximize net returns by planting lettuce in newly developed sugarcane fields since yields remain profitable for 3 to 4 crop cycles. If production with susceptible cultivars extends for a longer period, negative net returns can be expected when prices reflect market conditions with both normal and short supplies. Since more than half of all cultivars planted in Florida are susceptible to $\mathrm{CR}$, the rotation suggested will minimize losses from $\mathrm{CR}$ while the industry increases the availability of resistant cultivars.

\section{Literature Cited}

Busch, L.V. and G.L. Baron. 1963. Root rot of head lettuce in Ontario. Can. J. Plant Sci. 43:166-173.

Datnoff, L.E. and R.T. Nagata. 1990. Isolation of Rhizomonas suberifaciens in Florida. Plant Dis. 74:394.

Datnoff, L.E. and R.T. Nagata. 1992. Relationship between corky root disease and yield of crisphead lettuce. J. Amer. Soc. Hort. Sci. 117:54-58.

D'Ercole, N. 1981. La suberosi radicale della lattuga. Terra Vita 41:40-41.

Florida Dept. of Agriculture and Consumer Services. 1990. Florida Agricultural Statistics, Veg etable summary 1988-89. Orlando.

Guzman, V.L. 1984. South Bay and Raleigh, two crisphead lettuce cultivars resistant to corky root for organic soils. Florida Agr. Expt. Sta. Circ. S-310.

O'Brien, R.D. and A.H.C. van Bruggen. 1990. Soil fumigation with dazomet and methyl bromide for control of corky root in iceberg lettuce. Plant Dis. 74:1022-1025.

Taylor. T.G. and S.A. Smith. 1989. Production costs for selected Florida vegetables, 1988-89. Univ. of Florida Food and Resource Econ. Dept. Econ. Info. Rpt. 257.

Taylor, T.G. and S.A. Smith. 1990. Production costs for selected Florida vegetables, 1989-90. Univ. of Florida Food and Resource Econ. Dept. Econ. Info. Rpt. 273.

U.S. Dept. of Agriculture. 1973. USDA standards for grades of lettuce. Agr. Mktg. Serv., Washington, D.C

van Bruggen, A.H.C., P.R. Brown, and K.N. Jochimsen. 1989. Corky root of lettuce caused by strains of a gram-negative bacterium from muck soils of Florida, New York, and Wisconsin. Appl. \& Eviron. Microbiol. 55:2635-2640.

van Bruggen, A.H.C., K.N. Jochimsen, and P.R. Brown. 1990. Rhizomonas suberifaciens gen. nov., sp. nov., the causal agent of corky root of lettuce. Intl. J. Syst. Bacteriol. 40 (2):175188. 